\title{
The Caddo
}

Edward R. Jelks

Unknown

Timothy K. Perttula

Heritage Research Center, Stephen F. Austin State University

Follow this and additional works at: https://scholarworks.sfasu.edu/ita

Part of the American Material Culture Commons, Archaeological Anthropology Commons, Environmental Studies Commons, Other American Studies Commons, Other Arts and Humanities Commons, Other History of Art, Architecture, and Archaeology Commons, and the United States History Commons

Tell us how this article helped you.

This Article is brought to you for free and open access by the Center for Regional Heritage Research at SFA ScholarWorks. It has been accepted for inclusion in Index of Texas Archaeology: Open Access Gray Literature from the Lone Star State by an authorized editor of SFA ScholarWorks. For more information, please contact cdsscholarworks@sfasu.edu. 


\section{The Caddo}

\section{Creative Commons License}

(c) (i) (8)

This work is licensed under a Creative Commons Attribution-NonCommercial 4.0 International License 


\title{
THE CADDO
}

\author{
Edward B. Jelks, with contributions by Timothy K. Perttula
}

This article was written in 1972 for inclusion in the Handbook of North American Indians, Vol. 14, to have been published by the Smithsonian Institution, Washington, D.C. For various reasons, neither the article nor the volume has appeared in print. The text of the article is essentially as originally written.

I am indebted to Tim Perttula for updating the article by making several changes in wording, by adding citations of relevant sources published since 1972, and by adding the end notes. I thank him too for arranging to have the article published in the Journal of Northcast Texas Archaeology.

Ed Jelks, May 2002

\section{SOURCES OF DATA}

Knowledge of early Caddo culture comes from both archaeological and ethnographic sources. Enough archaeological research had been completed by the early 1970 s to provide a fairly thorough chronology for the major pre-Columbian developments in the Caddoan area. and archaeological research has been extensive since that time (see recent general summaries in Early [2000a, n.d.] and Perttula [1996]).

Accounts of the De Soto expedition of 1541-1542 constitute the earliest source of ethnohistoric data on the Caddo. Translations of the De Soto documents may be found in Bourne (1904), Robertson (1933), Varner and Varner (1951), and more recently, Clayton et al. (1993). Some scholars think it likely that Coronado reached the edge of Caddo territory in 1541, but the consensus is strongly against that possibility (see Flint and Flint 1997). Swanton (1942:22-25) discusses the problcm cogently and gives translations of pertinent excerpts from the Coronado documents. Essays in Young and Hoffman (1993) consider the route and travels of the De Soto expedition, and its effects on the Caddo groups, as does Hudson (1997).

The next descriptions of the Caddo were made by Joutel and Douay, mernbers of La Sallc's short-lived Gulf Coast colony, in 1686 and 1687, and by Tonti, who came looking for La Salle in 1690 (Cox 1905; Foster 1998; Margry 1875-1886). Spanish efforts to establish missions among the Caddo tribes began in 1690 and continued intermittently until the 1770s. During that period, and in subsequent years prior to the Texas Revolution in 1836, many descriptions of Caddo customs and activities were recorded by mission priests, soldiers, and government officials of Spain and Mexico, the most notable being those of De Leon (Bolton 1916), Massanet (Bolton 1916), Teran de los Rios (Hatcher 1932), Casanas (1927), Espinosa (1927), Rubi (Heusinger 1936), Aguayo (Buckley 1911), Solis (1931), De Mezieres (Bolton 1914), Padilla (1919), Sanchez (1926), Bcrlandier (1969), and Mier y Teran (Jackson 2000).

Shortly after the French settled Louisiana in 1699, they turned their attention to trading with the Caddo, and some of the tradcrs left descriptions of them: La Harpe (Margry 1875-1886), St. Denis (Margry 1875-1886), and Gaignard (Bolton 1914). After Louisiana was ceded to Spain in 1762, the French documentation of the Caddo came to a halt. 
The Anglo-American frontier, unleashed by the Louisiana Purchase in 1803, swept into Caddo territory immediately after the turn of the 19th century, and accounts of the Caddo penned by Anglo-Americans provide the major source of ethnohistoric data thereafter: Freeman and Custis (1806; see also Flores [1984]), Sibley $(1832,1922)$, the Austin Papers (Barker 1924), the Texas Indian Papers (Winfrey 1959-1960), Neighbors (1847), Roemer (1935), Cooper (1851), Marcy (1855), and Schoolcraft (1851-1857). In the late 19th and early 20th centuries, scholars recorded some data taken from Caddo informants (e.g., Dorsey 1905; Parsons 1941; Swanton 1942). Several major secondary sources relating to the Caddo had appeared by the mid-20th century, including Bolton (1908, 1912, 1914, 1915, 1916, 1987), Castaneda (1936-1939), Glover (1935), Griffith (1954), Koch (1925), Lesser and Weltfish (1932), Muckelroy (1923), Newcomb (1961), and Swanton (1942), and a number of more recent works have been published on the Caddo (see Carter 1995; Gregory 1973; Hickerson 1996; La Vere 1998; Lesser 1979; Newkumet and Meredith 1988; Perttula 1992; Perttula and Bruseth 1998; Sabo 1987; Smith 1995, 1996; Wedel 1978; Williams 1964; Wyckoff and Baugh 1980; see also Perttula ct al. 1999 for a comprehensive bibliography on the Caddo Indians).

\section{THE CADDO TRIBES}

The Indians known today (1976) as the Caddo are descendants of some 15 to 20 separate tribes of the $17^{\text {th }}$ and $18^{\text {th }}$ centuries (Figure 1). The name Caddo comprises the first two syllables of Kadohadacho, one of the original tribes, and is derived from the Caddo word ka' ede or caddi, meaning chief (Swanton 1942:5-6). Although there is considerable variation in the names of tribes ascribed to the Caddo by different $17^{\text {th }}$ and $18^{\text {th }}$ century observers, the records refer consistently to 14 tribes, which were then organized into three-maybe four in the beginning-separate confederacies ${ }^{1}$, as follows:

Hasinai Confederacy (occupying the upper Neches and Angelina rivers)

Hainai (leading tribe of the confederacy)
Anadarko
Nabedache
Nacogdoche
Nacono
Namidish
Nasoni
Neche

$\underline{\text { Kadohadacho Confederacy (occupying the Great Bend area of Red River) }}$

Kadohadacho (leading tribe of the confederacy)

Nanatsoho

Nasoni

Natchitoches

Natchitoches Confederacy (occupying the lower Red River in the vicinity of Present-day Natchitoches, Louisiana)

Natchitoches (leading tribe of the confederacy)

Doustioni

As indicated in the above list, there were two groups of Nasoni and two groups of Natchitoches, so that each of those tribes was divided between two of the confederacies. 
These divisions were sometimes referred to respectively as Upper and Lower Nasoni and Upper and Lower Natchitoches.

Four related, but culturally divergent and more or less independent tribes were the Yatasi, Cahinnio, Hais (or Ais), and Adai. The Yatasi lived on Red River between the Kadohadacho and the Lower Natchitoches until 1717 when, after being attacked by the Chickasaw, they split into two groups, one joining the Kadohadacho Confederacy, the other the Natchitoches Confederacy. The Cahinnio, easternmost of the Caddo tribes, who lived on the upper Ouachita River in southwestern Arkansas, are linked by some reports to the Kadohadacho Confederacy.

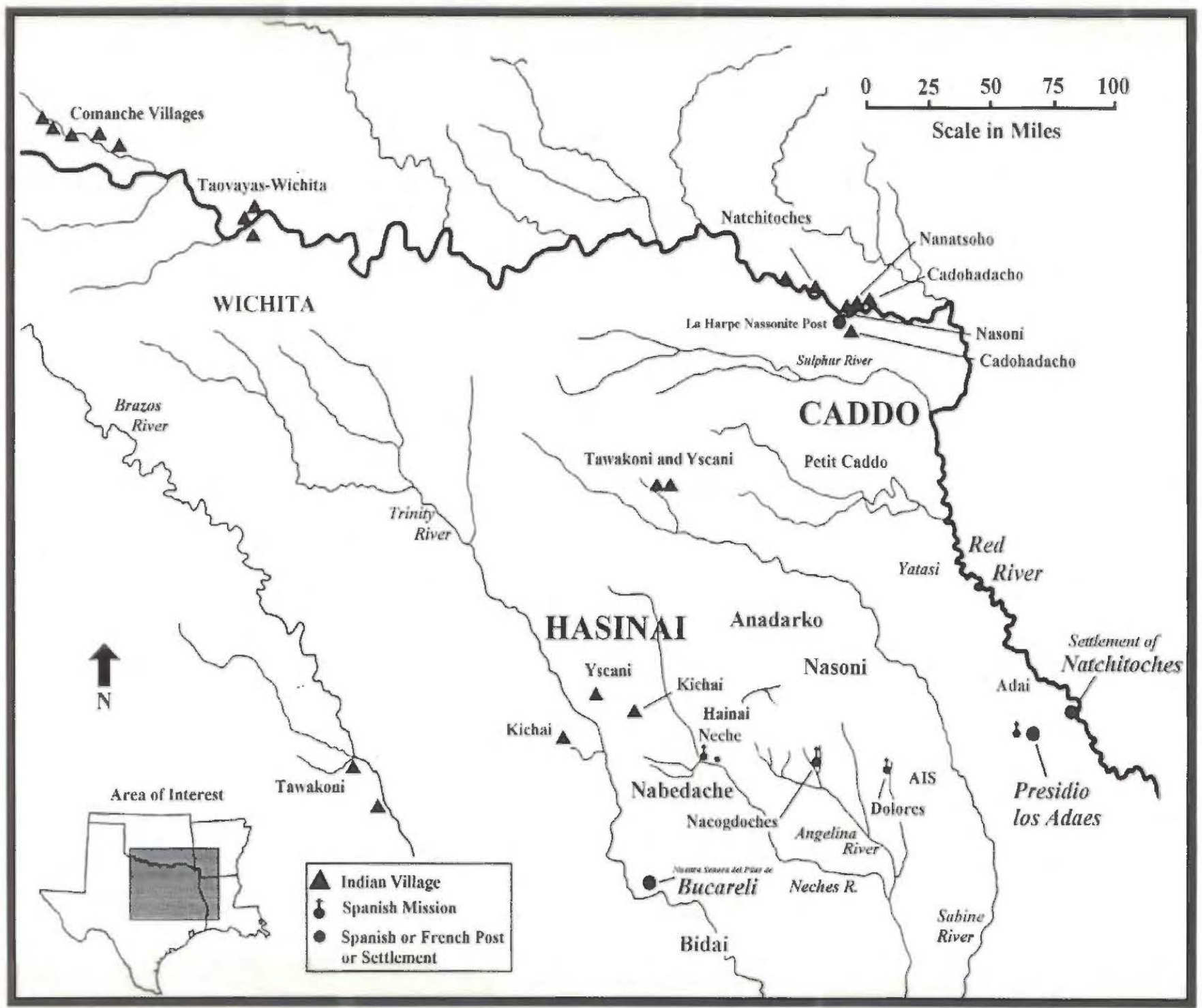

Figure 1. Caddo settlement locations during historic times (from Derrick and Wilson 2001). 
Betwcen the Hasinai and the Lower Natchitoches lived the Hais in the vicinity of modern San Augustine, Texas. ${ }^{2}$ Home of the Adai was east of the Sabine River, between the Hais and the Lower Natchitoches. The Adai and Hais were the most culturally divergent of the Caddo tribes. The namc Tejas, or Texas, was often used in reference to the Hasinai people, or sometimes to all the Caddo tribe collectively.

Other tribal names were identified in $16^{\text {th }}, 17^{\text {th }}$, and $18^{\text {th }}$ century documents as Caddo affiliates, but they are mentioned by only one or two observers, then are never heard of again. Just who these peoples were will probably never be known. Included among them were:

Tula, Amaye or Maye, Guasco, Naquiscoca, Soacatino, Nacacahoz (De Soto documents)

Daquio, Dotchetonne, Sacahaye, Chaye (Joutel)

Capiche, Nada, Choye (Tonti)

Guasco, Soacatino, Nechavi, Cataya, Tadivas, Nabeyeyxa, Nasayaya (Casanas)

Nachoos (St. Denis). ${ }^{3}$

\section{ENVIRONMENT}

The homeland of the historic Caddo and their prehistoric ancestors, from perhaps A.D. 700 or 800 until the end of the $18^{\text {th }}$ century, was a territory of some 30,000 square miles encompassing contiguous parts of what are now eastern Texas, northern Louisiana, southwestern Arkansas, and southeastern Oklahoma (see Figure 1), in the drainages of the Red, Ouachita, Sabine, and Neches rivers. This is the cxtreme western edge of the southeastern forest, right at the fringe of the Plains: the western part of the Lower Austral Life Zone of the Coastal Plain Physiographic Province (Hunt 1967:100-103, 147-160).

The region is characterized by pines on the upland (mixed with oaks, sweetgum, hickory, and other broad-leafed trees in the northern part) and cypress, pecan, oaks, walnut, willow, and a variety of shrubs in lowland areas. Fauna include opossum, raccoon, deer, bear, skunk, foxes, gophers, and squirrels. Turkey, dove, quail, and migratory waterfowl are abundant and the streams carry many specics of fish, turtle, and mussels. Elevation is less than 500 feet above sea level save at the northwestern edge where it rises somcwhat higher, and in the Ouachita Mountains. Temperatures are moderate and annual rainfall is 40 to 60 inches in modern times. The sandy soil can be cultivated with relative ease, even with hand tools. The topography is moderately hilly. The Caddo lovingly called it "the beautiful country" (Webb 1960:35).

The Caddo's neighbors were (going clockwise): Osage and Missouri to the north; Quapaw, Tunica, and Natchez to the east; Atakapa, Karankawa, and Bidai to the south; and the Tonkawa and the Wichita tribes (Tawakoni, Taovayas, and Kichai) to the west (see Figure 1). Thus, they were adjacent to sedentary southeastern farmers in one dircction, semi-nomadic foragers of the Gulf littoral in another, and hunting-farming Plainsmen in a third. And they shared culture traits with all three. 


\section{POPULATION}

Caddo censuses and population estimates are summarized in the following list. The data are from Swanton (1942:16-25), Wright (1951:53), and U.S. Department of the Interior (1971).

\section{Hasinai}

$\begin{array}{ll}\text { Year } & \text { Authority } \\ 1699 & \text { Anonymous } \\ 1716 & \text { Ramon } \\ 1721 & \text { Aguayo } \\ 1779 & \text { De Mezieres } \\ 1805 & \text { Sibley } \\ 1820 & \text { Padilla } \\ 1847 & \text { Bumet } \\ 1851 & \text { Stem } \\ 1864 & \text { Indian Officc } \\ 1876 & \text { Indian Officc }\end{array}$

\begin{tabular}{lc} 
Warriors & Total Population \\
\cline { 2 - 2 } $600-700$ & -- \\
-- & 40005000 \\
- & $1378+$ \\
135 & -- \\
200 & -- \\
-- & 1450 \\
- & 200 farnilies \\
$100+$ & $315+$ \\
-- & 150 \\
-- & 30
\end{tabular}

\section{Kadohadacho}

$\begin{array}{llll}\text { Year } & \text { Authority } & \text { Warriors } & \text { Total Population } \\ 1700 & \text { Bicnville } & 500-600 & - \\ 1709 & \text { Ia Harpe } & -- & 2500 \\ 1718 & \text { Bienville } & 200 & -- \\ 1719 & \text { La Harpe } & -- & 400 \\ 1773 & \text { De Mezieres } & 160 & - \\ 1805 & \text { Sibley } & 200 & - \\ 1820 & \text { Padilla } & -- & 2000 \\ 1825 & \text { Schoolcraft } & -- & 450 \\ 1851 & \text { Stem } & -- & 300 \\ 1857 & \text { Neighbors } & -- & 235+ \\ 1864 & \text { Indian Officc } & -- & 370 \\ 1876 & \text { Indian Office } & -- & 467\end{array}$

Natchitoches

$\begin{array}{llll}\text { Year } & \text { Authority } & \text { Warriors } & \text { Total Population } \\ 1700 & \text { Bienville } & 400-450 & - \\ 1718 & \text { Bienville } & 80 & -- \\ 1719 & \text { La Harpe } & -- & 200 \\ 1773 & \text { De Mczieres } & 3 & -- \\ 1805 & \text { Sibley } & 52 & -- \\ 1825 & \text { Schoolcraft } & -- & 61\end{array}$

\section{Adai}

$\begin{array}{llll}\text { Year } & \text { Authority } & \text { Warriors } & \text { Total Population } \\ 1700 & \text { Bienville } & 50 & \text {.- }\end{array}$




\begin{tabular}{|c|c|c|c|}
\hline \multirow{4}{*}{$\begin{array}{l}1718 \\
1721 \\
1805 \\
1825\end{array}$} & Bienville & 100 & \\
\hline & Aguayo & - & $400+$ \\
\hline & Sibley & 20 & -- \\
\hline & Schoolcraft & -- & 27 \\
\hline \multicolumn{4}{|c|}{ Hais } \\
\hline Year & Authority & $\underline{\text { Warriors }}$ & Total Population \\
\hline 1716 & French traders & -- & 320 \\
\hline 1779 & De Mczieres & -- & 80 \\
\hline 1805 & Sibley & -.. & 25 \\
\hline 1820 & Padilla & $\cdots$ & 300 \\
\hline 1828 & Muckleroy & -- & 640 \\
\hline \multicolumn{4}{|c|}{ Caddo (all tribes collectively) } \\
\hline 1880 & \multicolumn{3}{|c|}{538 ( 1.39 men, 156 women, 123 boys, 120 girls) } \\
\hline 1887 & \multicolumn{3}{|c|}{525 ( 256 males, 269 females, and including 121 children) } \\
\hline 1895 & \multicolumn{3}{|c|}{498} \\
\hline 1904 & \multicolumn{3}{|c|}{535} \\
\hline 1910 & \multicolumn{3}{|c|}{452} \\
\hline 1930 & \multicolumn{3}{|c|}{708 (353 males, 355 females) } \\
\hline 1937 & \multicolumn{3}{|c|}{967 (479 males, 488 females) } \\
\hline 1951 & \multicolumn{3}{|c|}{ est. 1125} \\
\hline 1971 & \multicolumn{3}{|c|}{3000 (including Wichita) } \\
\hline
\end{tabular}

The figures in the above lists show clearly that between 1700 and ca. 1870 there was a consistent decline in Caddo population. After that, the trend reversed, and total population has been increasing slowly since.

\section{SUMMARY OF CADDO CULTURE HISTORY}

A basic Caddo culture - the archaeological Gibson Aspect of the Mississippian tradition-became entrenched in the lower Red-Sabine-Neches region by A.D. 700-800. Some Gibson Aspect culture traits can be traced through time to the Caddo of the historic period, including maize agriculture, a distinctive ceramic lechnology, fronto-occipital hcad deformation, and trade with peoples of the American Southwest and other distant areas. Gibson Aspect peoples also erected both burial and temple mounds at large religious centers and had a well-developed ceremonialism involving elaborate paraphernalia identified with the so-called "southern cult," archeological evidence of which has been found all across the Southeastern states. The Fulton Aspect, which superseded the Gibson Aspect at roughly A.D. 1200, continued along much the same secular lines, but religious/ceremonial emphasis declined. Figure 2 shows the locations of post-A.D. 1400 
Caddo groups and archaeological phases in the Caddo archaeological area, with notably dense settlements on the Red River, the Ouachita River, the Big Cypress Creek basin, and the Neches-Angelina river basins. By the late $17^{\text {th }}$ century (and possibly before De Soto's entrada in 1541), the Caddo evidently were no longer building temple or burial mounds, although they may sometimes have used mounds built by their ancestors as burial spots or as bases for houses or other structures (Suhm et al. 1954:151-227; Webb 1960:42-53; Davis 1961b). ${ }^{4}$

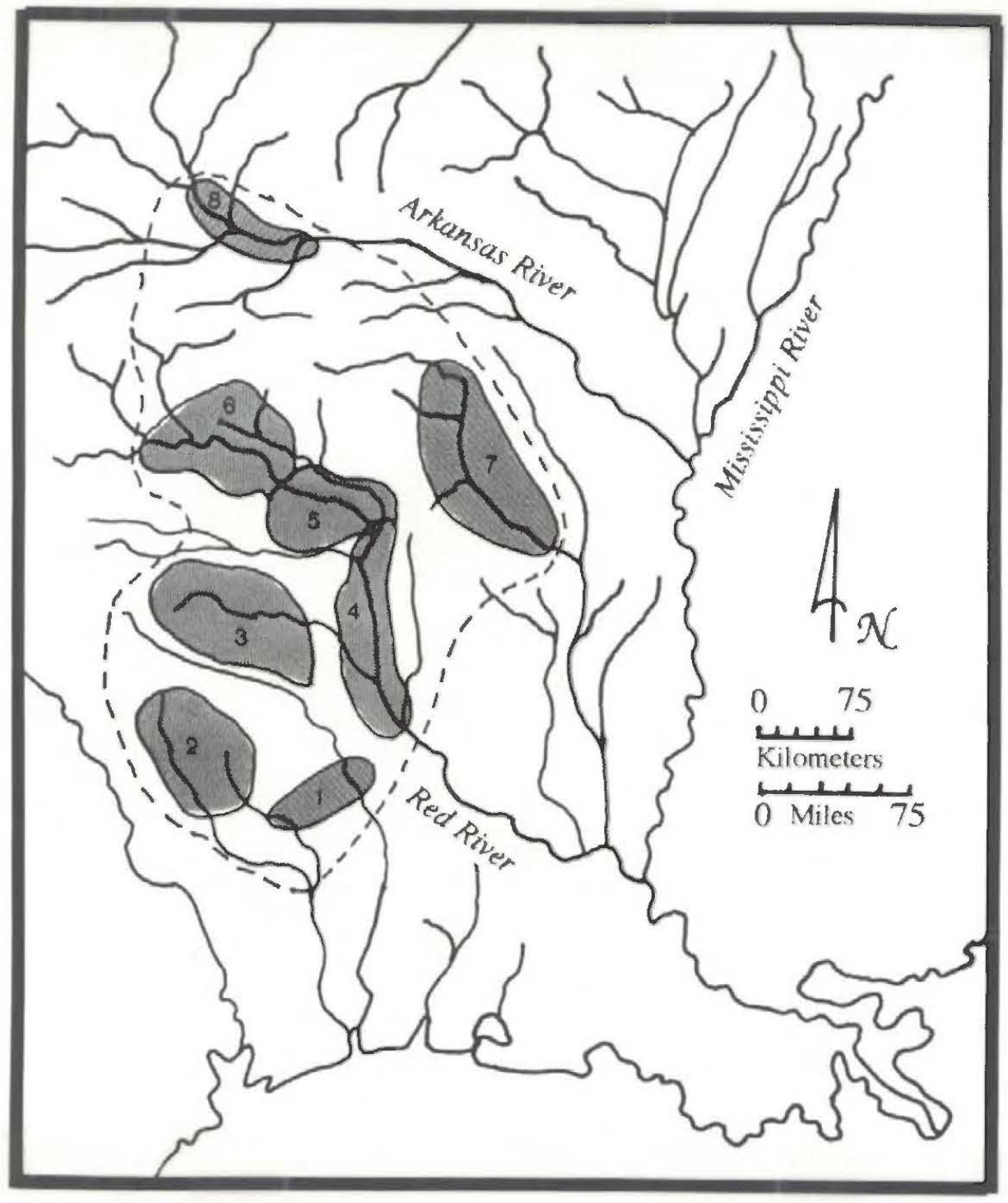

Figure 2. Post-A.D. 1400 Caddo phases: 1, Angelina; 2, Frankston; 3, Titus; 4, Belcher; 5, Texarkana; 6, McCurtain; 7, Mid-Ouachita and Social Hill; 8, Fort Coffee.

Following the somewhat sketchy accounts of the De Soto expedition (sce Hudson 1997), there are no detailed descriptions of Caddoan culture until La Salle and his followers appeared on the scene almost 150 years later (see Foster 1998; Margry 1875-1886). By then the Caddo had acquired horses and goods of European manufacture through their long-established trade routes with the Southwest. 
Once the French settlers in Louisiana had opened a brisk trade with the Caddo in the early $18^{\text {th }}$ century, the acculturation which had begun decades beforc increased greatly. French and Spanish efforts to expand their respective colonial $\mathrm{cmpires}$ caught the Caddo squarely in the middle, and excrtcd intense pressures which accelcratcd even more their adoption of European tools, clothing, weapons, religion, values, and customs. By 1762 when France ceded Louisiana to Spain, Caddo culture and society had been irremediably disrupted, not only by French and Spanish influences but also by incursions of other Indian tribes who were bcing forced toward the Caddo by pressure from European colonies far to the north and east. By the end of the $18^{\text {th }}$ century, cultural pressures from Europeans and Indians - combined with severe epidemics of smallpox, measles, and other European diseases (see Ewers 1973; Perttula 1992, 2001; Derrick and Wilson 2001)-had reduced what was once a populous, well-adapted socicty to a harassed, bewildered remnant, relentlessly being pushed out of their homeland and dependent on Europeans for wcapons, tools, and other necessities of life. Their political structure was disintegrating, with most of the major $18^{\text {th }}$ century tribes having totally disappeared by the $1820 \mathrm{~s}$, leaving only three: Kadohadacho, Anadarko, and Hainai (Swanton 1942:29-121; see also Smith 1995, 1996).

In 1835 the Caddo withdrew completely from United States territory, in accordance with a treaty signed that year between the United States and several Indian Iribes, and regrouped west of the Sabine River in country that had become a temporary sanctuary for refugec Choclaw, Cherokee, Alabama, Koasati (Coushatta), Biloxi, Delaware, Kickapoo, Shawnee, and other Indians from over most of eastern North America (see Everett 1990; Jurney 2001; Perttula 1993). By 1839 the Kadohadacho, Hainai, and Anadarko had moved westward to the central course of the Brazos River where they formed a close association with remnants of their old Wichita allies, the Tawakoni, Waco, and Kichai (see recent discussions on these groups by Newcomb [2001] and Parks [2001]). About 1850, keeping ahead of the White frontier, they retreated some 125 miles farther up the Brazos (Neighbors 1847; Cooper 1851; Marcy 1855; Roemer 1935: 197-203; Swanton 1942:89-102).

The three Caddo tribes were put on a reservation on the upper Brazos in 1855 along with the Waco, Tawakoni, Kichai, Tonkawa, and a few Delaware (see discussion in Sinith 1996); then in 1859 all the Indians on the Brazos reservation were removed to reservations in what is now western Oklahoma. The Caddo have remained there ever since except for a temporary dispersal of a small number of Caddo that relocated to southern Kansas during the American Civil War. For a while some tribal distinctions between Kadohadacho, Anadarko, and Hainai were maintained on the reservation, but by the beginning of the $20^{\text {th }}$ century the distinctions had disappeared and all were known simply as Caddo.

In the middle $20^{\text {th }}$ century most Caddo were Americanized ranchers and farmers, with well over half of them having mixed Indian-White blood. They lived on the WichitaCaddo Reservation, and later allotment and trust lands when the reservation was terminated, under administration of the Anadarko Area Office of the Bureau of Indian Affairs, and their children attended the local public schools along with White children.

'The Caddo Indian Tribe of Oklahoma was chartered under the Indian Welfare Act of 1936, and their tribal constitution and by-laws were ratified in 1938. The principal governing body is the Caddo Tribal Council. They no longer have a chief, and are led by the tribal chairperson; in 2002 the tribal chair is LaRue Parker. The Caddo have shown keen interest in preserving their traditions and have participated for many years in the dances and ceremonies of the annual exposition at Anadarko (Swanton 1942:102-113; Wright 1951:33-34, 51-53, 156; see also Meredith 2001). 


\section{SKETCH OF CADDO CULTURE}

In their general cultural pattern the Caddo were typical of the aboriginal farmers of the southeastern United States region, but thcy also shared in some typical Plains traits, for example: intensive bison hunting, grass-thatched houses like those of the Wichita, the use of skin tents whilc on the hunt, bison scapula hoes, and snub-nosed end scrapers of chipped stone. Their linguistic affinities lay with the Plains area too.

\section{Settlement Pattern}

Most Caddos lived in tiny hamlets scattered a quarter of a mile to a mile apart, one hamlet having perhaps 10 to 12 dwellings, each housing several nuclear families. Fach hamlet farmed its surrounding fields. The hamlets of a particular tribe occupied, on the average, an area some 10 to 30 miles across, within which was a central town that served as a ceremonial center and wherein dwelled the tribal chief (Bolton 1908:270-271; Cox 1905, Vol. 1:232; Hidalgo 1927:56).

\section{Language}

The language spoken by the Caddo was included by Powell $(1891: 45-46,58-62)$ in the Caddoan linguistic stock, along with the languages of the Kichai, Wichita, Tawakoni, Waco, Pawnee, and Arikara. Cadduan has continued to be recognized as a major North Amcricans linguistic stock or family by specialists (e.g., Lesser and Weltfish 1932; Voegelin 1941:26; Driver 1969:44), all of whom include the languages of the Wichita, Pawnee, and Arikara in the stock along with that of the Caddo (sec also Goddard 1996).

There were dialectic differences between the different Caddo tribes but they were minor; consequently a member of one tribe usually had no difficulty talking to a member of another, save for the Adai and the Hais, each of which spoke a language mutually unintelligible to any of the other tribes. The Caddo were adept at sign language which they used for communicating with non-Caddos such as their Wichita friends. They also are reported to have used smoke signals with great effectiveness for transmitting messages quickly from tribe to tribe across long distances (Swanton 1942:176, 190).

\section{Political Organization}

Fach tribe had its own chief or caddi, and each of the confedcracies had a grand chicf or xinesi. The latter, who inherited his office through dircct line of descent from father to eldest son, was greatly revered and feared but had little real political power. Seemingly his primary function was ceremonial: to keep a perpetual fire going in the central temple of the confederacy, to act as an oracle, and to perform other priestly duties on behalf of all the confederates tribes.

The tribal chiefs, whose office was also hereditary, settled disputes, scheduled cercmonies, and handlcd other intra-tribal matters, often after counseling with sub-chiefs and tribal elders. War chicfs were elected popularly.

Political bonds between the tribes of a confederacy were quite loose, and apparently there wcrc none at all betwcen the three confedcracies. Most matters of governance wcre resolved at the tribal level by the chief, by lesser officials, or often, no doubt, by heads of kin groups (Casanas 1927:215-216, 218, 286; Espinosa 1927:160, 175-176; Swanton 1942:170-173; Griffith 1954:59-67; Newcomb 1961:303-304). 


\section{Food}

The Caddo subsisted primarily on agricultural products: two varieties of maize (early and late maturing), pumpkins, sunflower seeds, and five or six kinds of beans. ${ }^{6}$ Men and women collaborated in preparing the fields for planting, but the planting, cultivating, and harvesting were done entirely by women. Hoes with wooden or bison scapula blades were the principal agricultural tool.

Bison and deer provided most of their meat, but other mammals were also eaten, including bear and rabbit. After horses had been acquired the men went on at least one hunting expedition every year into bison country to the west, usually in winter, and brought home sun-dried meat and hides in large quantities. In earlier times they presumably conducted bison hunts on foot. Deer may have furnished as much meat as bison, especially in pre-horse days. Fish were a staple item of diet, as were prairie chicken, ducks, geese, turkeys, cranes, and various small birds.

Large game was hunted with the bow and arrow, fish were caught on trotlines, and though there is little ethnohistoric data bout them, snares, traps, and nets must have been utilized for catching fish, birds, and small game. Women seasonally collected such wild vegetal foods as acorns, nuts, seeds, grapes, berries, roots, and fruits, often in large quantities.

Fresh maize was roasted or boiled. Dried maize and acorns were reduced to meal by pounding in deep wooden mortars made from hollowed-out tree trunks and the meal made into bread and porridge. Meat was boiled and roasted. Tamales made from whole or ground maize were a favorite, as was succotash compounded of maize, beans, and other vegetables. Salt and bear fat were added to many dishes for seasoning.

Most food was cooked in earthenware vessels. Diners were served individually in earthenware bowls and shallow baskets from which they ate with the fingers.

While occasional crop failures from droughts or other crises inevitably must have put them on short rations at times, the Caddo generally had an abundant food supply. Farm produce, acorns, nuts, and the like were stored in large reed baskets, and a two-year supply of seeds for planting was carefully preserved, even through times of famine (Margry 1875-1886, Vol. 3:367, 394-395, 466-469; Casanas 1927:211, 217; Espinosa 1927:152-157; Hidalgo 1927:56; Solis 1931:43; Morfi 1932:44; Swanton 1942:127; Griffith 1954:107-120; Newcomb 1961:292-294).

\section{Domesticated Animals}

The Caddo's only domesticated animal was a kind of sharp-nosed dog that was used for hunting, although his role in the hunt was not explained. Apparently dogs were eaten rarely on ceremonial occasions or in times of famine (Griffith 1954:108; Swanton 1942:134). In prehistoric Caddo archaeological sites, dogs were sometimes placed in their own graves, but other evidence suggests they were occasionally eaten for food.

\section{Dress and Appearance}

Clothing, mostly of deerskin, was typically Southeastern. Men wore breech clouts and went barefoot in warm weather, and donned shirts, leggings, moccasins, or occasionally bison-skin cloaks in winter. Women wore grass breech clouts under deer skin skirts and poncho-like blouses. Clothing was heavily ornamented with painted designs, 
fringes, feathers, and beads. Textiles and mulberry-bark cloth probably were used for clothing despite the lack of references to either.

Both sexes tattooed their faces, breasts, and shoulders by rubbing charcoal into pricked designs, each tribe having its own design motifs. Hair styles varied from tribe to tribe. Fronto-occipital head deformation was practiced (see Derrick and Wilson 1997), and body hair was commonly removed. The body was decorated profusely with hair feathers, fur strips, bracelets, necklaces, gorgets, nose omaments, ear plugs, and the like (Casanas 1927:213-214, 285; Espinosa 1927:176-177; Solis 1931:42, 60; Margry 1875-1886:349; Swanton 1942:140-148; Griffith 1954:97-98; Newcomb 1961:289-290; Jackson 2000:77).

\section{Manufactures, Crafts, and Arts}

Archaeological studies have shown that before trade with Europeans began, the Caddo knapped knives, scraping tools, arrow points, and other cutting and piercing tools from siliccous stones, shaped celts (probably for hewing wood) from various hard stones by pecking and grinding, and sharpened splinters of bone into awl-like tools that evidently were used for sewing skins and weaving baskets and mats. Mussel shells served as spoons and hoe blades. Bison scapulas were also used for hoe blades, and deer ulnas were shaped into spatulate flint knapping tools. Flat slabs of sandstone became nether stones on which maize and other seeds were ground into meal with loaf-shaped hand stones or manos.

A variety of personal ornaments-beads, pendants, gorgets, and ear plugs - was fashioned from marine shells, freshwater mussel shells, bone, quartz, ocher, native copper (imported from the Great Lakes region), and other materials. Tobacco pipes were made of both stone and earthenware. Earthenware vessels were made in many shapes and sizcs, most of them beautifully decorated with pleasing designs executed by incising, punctating, applique, engraving, excising, or modeling. Ceramic art of the Southeastern Indians surely reached its peak among the Caddo (sce Suhm et al. 1954:151-227; Webb 1960:48-53; a few of the more recent summary studies of Caddo Indian ceramics include Schambach and Miller 1984; Early 1988, 1993; Perttula et al. 1995; Kelley 1997).

Manufactures, crafts, and arts documented by historical accounts include: wooden hoes, boxes, benches, statues, drums, mortars and pestles, fire drills, fire tongs, bows, dugout canoes, and notched musical rasps; clothing and robes made of deer and bison skin and woven cloth; a great variety of baskets and mats woven from reeds and fibers; bark cordage; gourd musical rattles; bird bone flageolets; artistic feather work both for personal adornment and for embellishing ceremonial paraphernalia; painted designs on clothing and mats; and body painting and tattooing. The Caddo were renowned among Europeans for the colorful decorations with which they adorned their clothing, utensils, tools, and accouterments (Bolton 1916:378; Casanas 1927:212-217, 291; Espinosa 1927:151, 160169, 173-174, 177; Hidalgo 1927:56; Margry 1875-1886, Vol. 3:353, Vol. 5:467-469; Swanton 1942:154-159; Griffith 1954:103-107; Newcomb 1961:297-298).

\section{Architecture}

Caddo houses typically were tall, circular, grass-thatched structures with the door facing east, virtually identical to those of the Wichita tribes. They were framed by first implanting the butts of slender, trimmed tree trunks in the ground one to three feet apart to form a circle some 40 to 60 feet in diameter, then bending their tops inward to the center of the circle and binding them together. ${ }^{8}$ Horizontal laths were then tied onto the upright poles and a heavy layer of grass thatch lashed to them. The completed houses were some $\mathbf{4 0}$ to 50 feet high. Smoke from a centrally located fireplace either diffused through the thatch or exited through a smokehole in the roof. Archaeological evidence indicates that the walls of 
some prehistoric Caddo houses were plastered with mud (see Early 2000b; Jelks and Tunnell 1959; Webb 1959), a construction method also employed between 1868 and 1872 (see Swanton 1942:Plate 14). Plastering is not mentioned, however, in documentary sources.

Beds were arranged around part of the interior house wall, separated from one another with skin curtains. Robes of deer or bison skin served as mattresses and coverings. Shelves along the rest of the wall space held large baskets and pottery vessels in which maize, beans, acorns, and other comestibles were stored. Seed maize in the shuck was strong on poles above the fireplace where smoke safeguarded it from vermin.

Outbuildings were grouped around the dwellings: high platforms for storing grain and open-sided sheds with a raised floor two or three feet off the ground. Public buildings included temples built like dwellings, but larger, and assembly houses where warriors lived while preparing for military expeditions (Margry 1875-1886:345, 393-394; Cox 1905; Bolton 1916:378; Espinosa 1927:154-155, 160; Hidalgo 1927:52; Roemer 1935:200; Webb 1940; Swanton 1942:148-154; Griffith 1954:99-102; Suhm et al. 1954:187-213; Newcomb 1961:294-297; Wilmsen 1961).

\section{Trade}

The prehistoric Caddo had artifacts made of copper, turquoise, obsidian, marine shells, and other exotic materials, the sources of which were hundreds of miles distant (see Brown 1983, 1996; Schambach 2000). Becausc of the pre-existing trade system, the Caddo acquired horses and manufactured goods from Spanish settlements in Mexico and New Mcxico well before the end of the $17^{\text {th }}$ century. In the $17^{\text {th }}$ and $18^{\text {th }}$ centuries they were trading bows made of highly prized bois d'arc wood, which grew locally, to both the east and the west; they were also engaged in trading salt (see Early 1993; Schambach 2000; Kenmotsu 2001)?

Throughout the $18^{\text {th }}$ century intensive trade was carried on with the French of Louisiana, from whom the Caddo obtained guns, metal tools, glass beads, and other goods in exchange for horses and animal hides (Cox 1905, Vol. 1:48, 232-235; Bolton 1914, Vol. 1:132-136, 139-140, 143-146, 149-150; Casanas 1927:285; Solis 1931:61, 67; Swanton 1942:192-203; Griffith 1954:122-123, 146-151; Suhm et al. 1954:161-227).

\section{Warfare}

Before Europeans appeared the Caddo evidently were on peaceful terms with most of their neighbors but carried on warfare with some traditional enemies, primarily for gaining personal prestige through the taking of scalps, heads, and prisoners. ${ }^{10}$ They later turned to stealing horses from the Spanish settlements and from various Indian tribes to trade for guns, iron tools, and other commodities with the French.

The Caddo were highly respected as fighting men by Europeans, who reported them to be experts with bow and arrow, musket, dagger, sword, and lance. For protection in battle they wore helmets and jackets of leather and carried shields of the same material. They fought under the leadership of popularly elected captains (Margry 1875-1886, Vol. 3:354-355, 374-381; Casanas 1927:217; Espinosa 1927:174; Hidalgo 1927:57; Solis 1931:42-43; Morfi 1932:50, 53; Swanton 1942:184-192; Griffith 1954:125-133; Newcomb 1961:306-308). 


\section{Religion}

Few details about Caddo religious beliefs have been recorded and preserved, but it is known that they believed in a supreme being, the "chief in the sky," and in an afterlife. The focus of religious activity was a temple administered by the grand chief where a perpetual fire was kept burning, the source of all household fires in the community (see a recent consideration by Sabo 1998).

Ceremonies and rituals-most of them partly religious, partly social in function-were associated with many activitics: hunting, warfare, planting and harvesting crops, greeting visitors, burying the dead, and consecrating houses and agricultural tools. Most ceremonies were conducted by shamans and chiefs. Tobacco and peyote were used in some of them (Margry 1875-1886:400-401; Casanas 1927:284, 301-302; Espinosa 1927:158-164, 168-175, 290-292; Hidalgo 1927:52; Swanton 1942:203-219, 226-234; Griffith 1954:69-87; Newcomb 1961:308-313).

\section{Social Status}

The bulk of Caddo society was essentially egalitarian. However, there was some stratification-chiefs, subchiefs, petty officials, shamans, and perhaps renowned warriors having special statuses. Chiefs were exalted and clearly were thought to possess some measure of divinity (Griffith 1954:67-68).

\section{Marriage}

Marriage of a previously unwed woman was effected by her family's acceptance of gifts left at the door by the prospective groom. There was no formal ceremony. If a man and a previously married woman wished to be married they simply bcgan living together. Marriages were usually monogamous, though both polygyny and polyandry were known. Marriages tended to be unstable as either spouse could terminate a marriage at will by just moving out (Casanas 1927:283-284; Espinosa 1927:164-165; Morfi 1932:44-45; Swanton 1942:160-162; Griffith 1954:92-93; Newcomb 1961:300-301).

\section{Division of Labor}

Men made weapons and moccasins, dressed skins, hunted, warred, helped clear fields for farming, and helped build houses. Women planted and harvested crops, did all the housework, made basketry and pottery, dressed skins, helped build houses, and foraged for wild vegetal foods (Margry 1875-1886, Vol. 3:363-364; Casanas 1927:215; Espinosa 1927:177; Swanton 1942:162-163; Griffith 1954:121-122; Newcomb 1961:298).

\section{Kinship}

The original kinship system of the Caddo was not recorded, but some of its features can be reconstructed confidently. The Kadohadacho of the $17^{\text {th }}$ and $18^{\text {th }}$ centuries had four social groupings identified respectively with the totem animals beaver, otter, wolf, and lion (Morfi 1932:6). In the late $19^{\text {th }}$ century Mooney (1896:1093) reported 10 totems-eagle, raccoon, crow, thunder, panther, bear, wolf, buffalo, beaver, and sun-remembered by informants as having formerly been associated with clan-like social divisions. There is no proof that they were exogamous.

Descent seems to have been reckoned matrilineally, and a married couple apparently lived with the bride's family, at least temporarily. The several nuclear families reported to have occupied each house in the $17^{\text {th }}$ and $18^{\text {th }}$ centuries probably constituted extended 
families, and each hamlet made up of several houses may have been the locus of a related group (Spier 1924; Swanton 1931, 1942:163-169; Morfi 1932:6, 26; Newcomb 1961:304$306)$.

\section{SUMMARY}

The Caddo lived in their "beautiful country" for a thousand years or more. Throughout their millennium of independence they maintained a highly developed, stable culture-one with a sound economic base, an efficient technology, a sophisticated art, and a rich ceremonialism. Then, suddenly, they found themselves caught up as a pawn in the machinations of Spain and France as those two nations vied for control of the TexasLouisiana region, and they saw the fabric of their society sundered by the irresistible forces of international politics. But though decimated, they have survived tenaciously (see Carter 1995).

In the end Caddo, French, and Spanish culture alike gave way to modern American culture-a hybrid culture synthesized largely from European, Indian, and African constituents which developed its own distinctive configuration. As the first quarter of the $21^{\text {st }}$ century begins, the Caddo-an integral part of that American culture-continue in their efforts to improve their social and economic status within it, while, at the same time, strengthening consciousness of their Indian heritage.

\section{END NOTES}

1. The general consensus by Caddo scholars today is that the term "confederacy" is not an appropriate term for the relationship of tribes within each of the larger Kadohadacho, Hasinai, and Natchitoches groups. Instead, it may be more appropriate to refer to these relationships as "alliances," based on kin relations. Lee (2001:15-16) suggests that a model of daughter communities affiliated with core groups, the latter known by the terms Kadohadacho and Hainai, and the daughter Caddo groups are not "individual, autonomous groups, these east/west daughter communities maintain relations to each other, and seem to be affiliated with one core or the other. But, they are kin, not confederates."

2. Corbin et al. $(1980,1990)$ summarizes extensive archacological investigations at Mission Dolores de los Ais in San Augustine, built by Spanish missionaries in the sccond decade of the $18^{\text {th }}$ century for the Ais or Hais tribe.

3. Thomas N. Campbell has prepared numerous summaries for the $1996 \mathrm{New}$ Handbook of Texas (published by the Texas State Historical Association) on many other Caddo tribal names and associated ethnographic and historical information on them (see listing in Perttula et al. 1999:47-48).

4. The terms Gibson Aspect and Fulton Aspect are no longer employed by Caddo archaeological researchers. In Northeast Texas, the chronological framework proposed by Story (1990) is most commonly used, namely: Formative Caddoan (A.D. 8001000); Early Caddoan (A.D. 1000-1200); Middle Caddoan (A.D. 1200-1400); Late Caddoan (ca. A.D. 1400-1680); and Historic Caddoan (A.D. 1680-1860+). The Formative, Early, and Middle Caddoan periods of Story (1990) are roughly coeval with the older Gibson Aspect, and the Late Caddoan period is generally the same chronologically as sites that were identified as Fulton Aspect in the 1950s and 1960s. 
5. Unless otherwise indicated, the culture elements described in this section are traditional ones that survived into the $18^{\text {th }}$ century. Most source material is based on observations of the Hasinai and, to a lesser extent, the Kadohadacho, by Spaniards and Frenchmen; primary data on the Natchitoches Confederacy are meager. This account is generalized for all the Caddoan tribes, although most contemporary observations were on specific tribes [this end note accompanied the original 1972 MS prepared by Jelks].

6. Archacological evidence for the cultivation of maize, beans, and squash, sunflowers, and other weedy annuals is relatively abundant in sites investigated across the Caddoan archaeological area. However, maize is poorly represented in the archaeological record before ca. A.D. 700-900, and it appears to be the case that although maize is present among prehistoric Caddo groups, it did not become the most important and primary plant food resource until after ca. A.D. 1200-1300 (Perttula 1996:314-322).

7. The archaeological record also suggests that a wide variety of animals were procured and eaten by the Caddo groups. Deer, turkey, and aquatic species were the most important resources, although riverine and aquatic species (especially catfish, gar, and freshwater drum) were more abundant and commonly used by Caddo groups living in the Red River valley. Caddo sites found outside of the major southeastern floodplain habitats are characterized by woodland and forest-edge terrestrial species, with little use of aquatic resources (Perttula 1996:318). Bison is rarely represented in Caddo archacological sites outside of the Arkansas River basin in eastern Oklahoma, and in that area, the relative abundance of bison increased fourfold between A.D. 1200-1450 and A.D. 1450-1600 (Wyckoff 1980).

8. In archaeological contexts, most prehistoric and early historic Caddo house structures may be only 6-9 m (20-30 feet) in diameter, although they almost always have a central hearth with an underlying posthole. They also do not always face east, as in historic times. One $18 \mathrm{~m}$ structure has been reported from underneath Mound B at the George C. Davis site (Story 1997:72), and others of similar size have been documented under Mound A at the same site (Story 1997, 1998). Structures in the village were considerably smaller than those under the mounds, suggesting the mound structures were special-purpose or public buildings. Prehistoric Caddo structures were not always circular, as rectangular and square structures have been reported from various archaeological sites across the Caddo archaeological area (see Early 2000b).

9. There is archaeological evidence to suggest that the Caddo were engaged in longdistance exchange of items such as salt and bois d'arc, and many other items, as early as ca. A.D. 1000. The period between A.D. 1000-1300 may have been the epogee of the Caddo long-distance trade network. Salt production and salt trade became common among certain prehistoric Caddo groups between A.D. 1200-1600 (see Early 1993; Kenmotsu 2001).

10. There is almost no concrete evidence in the archaeological record for warfare or violent conflict between the Caddos and other peoples. Obviously in historic times there were conflicts between the Caddo peoples and their neighbors. These conflicts were rarely battles with large numbers of casualties on either side.

11. To date, no Caddo archaeological sites have been found where tobacco was definitely being grown and used, despite the fact that almost all prehistoric and early historic Caddo sites have clay pipe and pipe sherd fragments. Charred tobacco seeds are very small, and quite difficult to recover in soil samples, however, without the use of very fine mesh and extensive flotation recovery. Peyote also has not been found in Caddo archaeological contexts, but circular scroll stylistic motifs on certain Ripley Engraved 
vessels (Thurmond 1990:Figure 6c, e) closely resemble peyote buttons (see Tunnell 2000:Figure 1) and peyote symbolism (Curtis Tunnell, July 6, 2000, personal communication via e-mail with Timothy $\mathrm{K}$. Perttula). This information suggests that Late Caddoan Titus phase groups may have been using peyote as early as ca. A.D. $1400-1450$.

\section{REFERENCES CITED}

Almonte, Fray Juan N.

1925 Statistical Report on Texas. Translated by Carlos E. Castaneda. Southwestern Historical Quarterly 28(3):177-222.

Arricivita, Fray Juan Domingo

1792 Cronica Serafica del Colegio de Propaganda Fide de la Santa Cruz de Queretaro en la Nueva Espana Dedicada al Santisimo Patriarca Senor San Joseph. $2^{\text {nd }}$ Part.

Barker, Eugene C. (editor)

1924 The Austin Papers. Annual Report of the American Historical Association for the Year 1919. American Historical Association, Washington, D.C.

Bell, Robert E. and David A. Baerreis

1951 A Survey of Oklahoma Archeology. Bulletin of the Texas Archeological Society 22:7-100.

Bennett, Kenneth A.

1961 Artificial Cranial Deformation Among the Caddo Indians. Texas Journal of Science 13(4):377-390.

Berlandier, Jean L.

1969 The Indians of Texas in 1830. Edited and introduced by John C. Ewers. Translated by Patricia Reading Leclerq. Smithsonian Institution Press, Washington, D.C.

Bolton, Herbert E.

1908 The Native Tribes About the East Texas Missions. Quarterly of the Texas State Historical Association 11(4):249-276.

1912 The Spanish Occupation of Texas, 1519-1690. Southwestern Historical Quarterly 16(1):1-26.

1914 (editor) Athanase de Mezieres and the Louisiana-Texas Frontier, 1768-1780. 2 Vols. Arthur H. Clark Co., Cleveland.

1915 Texas in the Middle Eighteenth Century. Publications in History, Vol. 3. University of California, Berkeley.

1916 (editor) Spanish Exploration in the Southwest, 1542-1706. Charles Scribner's Sons, New York.

1987 The Hasinais: Southern Caddoans as seen by the Earliest Europeans. University of Oklahoma Press, Norman. 
Bourne, Edward G. (editor)

1904 Narratives of the Career of Hernando De Soto. 2 Vols. A. S. Barnes and Co., New York.

Brown, James A.

1983 Spiro Exchange Connections Revealed by Sources of Imported Raw Materials. In Southeastern Natives and Their Pasts, edited by Don G. Wyckoff and Jack L. Hofman, pp. 129-162. Studies in Oklahoma's Past No. 11. Oklahoma Archeological Survey, Norman.

1996 The Spiro Ceremonial Center: The Archaeology of Arkansas Valley Caddoan Culture in Eastern Oklahoma. 2 Vols. Memoir No. 29. Museum of Anthropology, University of Michigan, Ann Arbor.

Buckley, Eleanor C.

1911 The Aguayo Expedition into Texas and Louisiana, 1719-1722. Quarterly of the Texas State Historical Association 15(1):1-65.

Carter, Cecile E.

1995 Caddo Indians: Where We Come From. University of Oklahoma Press, Norman.

Carter, Clarence E.

1951 The Territory of Louisiana-Missouri, 1815-1821. The Territorial Papers of the United States 15. Washington, D.C.

1953 The Territory of Arkansas, 1819-1825. The Territorial Papers of the United States 19. Washington, D.C.

1954 The Territory of Arkansas, 1825-1829. The Territorial Papers of the United States 20. Washington, D.C.

Casanas, Fray Francisco

1926-1927 Descriptions of the Tejas or Asinai Indians, 1691-1722. Translated from the Spanish by Mattie Austin Hatcher. Parts I and II: Fray Francisco Casanas de Jesus Maria to the Viceroy of Mexico. Southwestern Historical Quarterly 30:206-218, 283-304.

Castaneda, Carlos E.

1936-1939 Our Catholic Heritage in Texas, 1519-1936. 4 Vols. Von Boeckmann-Jones Co., Austin.

Clark, Robert C.

1902 Louis Juchereau de Saint Denis and the Reestablishment of the Tejas Missions. Quarterlyof the Texas State Historical Association 6(1):1-26.

Clayton, Lawrence A., Vernon J. Knight, Jr., and Edward C. Moore (editors)

1993 The De Soto Chronicles: The Expedition of Hernando de Soto to North America in 1539-1543. 2 Vols. University of Alabama Press, Tuscaloosa.

Cooper, S.

1851 Report to the Secretary of the Interior, July 23, I851. Records of the Bureau of Indian Affairs, Letters Received, 1849, Texas, I-752. National Archives, Washington, D.C. 
Corbin, J. E., T. C. Alex, and A. Kalina

1980 Mission Dolores de los Ais. Papers in Anthropology No. 2. Stephen F. Austin State University, Nacogdoches.

Corbin, J. E., H. A. Brown, M. G. Canavan, and S. Toups

1990 Mission Dolores de los Ais (41SA25): San Augustine County, Texas, Archaeological Investigations, 1984. Papers in Anthropology No. 5. Stephen F. Austin State University, Nacogdoches.

Cox, Isaac J.

1904 (editor) The Journeys of Rene Robert Cavelier, Sieur de La Salle. 2 Vols. Allerton Book Company, New York.

1914 The Louisiana-Texas Frontier, II. Southwestern Historical Quarterly 17(1):1-43.

Davis, E. Mott (editor)

1961a Proceedings of the Fourth Conference on Caddoan Archeology. Bulletin of the Texas Archeological Society 30:1-33.

1961b Proceedings of the Fifth Conference on Caddoan Archeology. Bulletin of the Texas Archeological Society 31:77-143.

Delanglez, Jean

1945 El Rio Del Espiritu Santo. Monograph Series 21. United States Catholic Historical Society, New York.

Derrick, Sharon M. and Diane E. Wilson

1997 Cranial Modeling as an Ethnic Marker among the Prehistoric Caddo. Bulletin of the Texas Archeological Society 68:139-146.

2001 The Effects of Epidemic Disease on Caddo Demographic Structure. Bulletin of the Texas Archeological Society 72:91-103.

Dickenson, Samuel D.

1941 Certain Vessels from the Clements Place, an Historic Caddo Site. Bulletin of the Texas Archeological and Paleontological Society 13:117-132.

Dorsey, George A.

1905 Traditions of the Caddo. Publications No. 41. Carnegie Institute of Washington, Washington, D.C.

Driver, Harold E.

1969 Indians of North America. $2^{\text {nd }}$ Edition. University of Chicago Press, Chicago.

Dunn, WilliamE.

1915 Spanish and French Rivalry in the Gulf Region of the United States, 1678-1702. University of Texas Publications, Austin.

Du Pratz, Le Page M.

1774 The History of Louisiana or of the Western Parts of Virginia and Carolina. Printed for T. Becket, London. 
Early, Ann M.

1988 Standridge: Caddoan Settlement in a Mountain Environment. Research Series No. 29. Arkansas Archeological Survey, Fayetteville.

1993 (editor) Caddoan Saltmakers. Research Series No. 49. Arkansas Archeological Survey, Fayetteville.

2000a The Caddos of the Trans-Mississippi South. In Indians of the Greater Southeast, edited by Bonnie G. McEwan, pp. 122-141. University Press of Florida, Gainesville.

2000b (editor) Forest Farmsteads: A Millennium of Human Occupation at Winding Stair in the Ouachita Mountains. Research Series 57. Arkansas Archeological Survey, Fayetteville.

n.d. Interior Southeast West of the Mississippi Valley after 500 B.C. MS submitted to Handbook of North American Indians, Smithsonian Institution, Washington, D.C.

Espinosa, Fray Isidro Felis de

1927 Descriptions of the Tejas or Asinai Indians, 1691-1722. Translated from the Spanish by Mattie Austin Hatcher. Part IV: Fray Isidro Felis de Espinosa on the Asinai and Their Allies. Southwestern Historical Quarterly 31:150-180.

Everett, Diane

1990 The Texas Cherokee: A People Between Two Fires, 1819-1840. University of Oklahoma Press, Norman.

Ewers, John C.

1973 The Influence of Epidemics on the Indian Populations and Cultures of Texas. Plains Anthropologist 18(60):104-115.

Flint, Richard and Shirley C. Flint (editors)

1997 The Coronado Expedition to Tierra Nueva: The 1540-1542 Route Across the Southwest. University Press of Colorado, Niwot.

Flores, Dan L. (editor)

1984 Jefferson and Southwestern Exploration: The Freeman and Custis Accounts of the Red River Expedition of 1806 . University of Oklahoma Press, Norman.

Foreman, Grant

1946 The Last Trek of the Indians. University of Chicago Press, Chicago.

Foster, William C. (editor)

1998 The La Salle Expedition to Texas: The Journal of Henri Joutel, 1684-1687. Texas State Historical Association, Austin.

Freeman, Thomas and Peter Custis

1806 An Account of the Red River in Louisiana, Drawn up from the Returns of Messrs. Freeman and Custis to the War Office of the United States, Who Explored the Same in the Year 1806. Washington, D.C. 
French, Benjamin F. (editor)

1843-1846 Historical Collection of Louisiana, Embracing Many Rare and Valuable Documents Relating to the Natural, Civil, and Political History of that State. 5 Vols. New York.

1875 Historical Collections of Louisiana and Florida. $2^{\text {nd }}$ Series. New York.

Glover, W. B.

1935 A History of the Caddo Indians. Louisiana Historical Quarterly 18(4):872-946.

Goddard, Ives

1996 The Classification of the Native Languages of North America. In Handbook of North American Indians, Volume 17: Languages, edited by Ives Goddard, pp. 290323. Smithsonian Institution, Washington, D.C.

Gregory, Hiram F.

1973 Eighteenth Century Caddoan Archaeology: A Study in Models and Interpretation. Ph.D. dissertation, Department of Anthropology, Southern Methodist University, Dallas.

Griffith, William J.

1954 The Hasinai Indians of East Texas as Seen by Europeans, 1687-1772. Philological and Documentary Studies 2(3):41-168. Middle American Research Institute, Tulane University, New Orleans.

Hackett, Charles W. (editor)

193 I Pichardo's Treatise on the Limits of Louisiana and Texas. University of Texas Press, Austin.

Harby, Mrs. Lee C.

1895 The Tejas: Their Habits, Government, and Superstitions. Annual Report of the American Historical Association , pp. 63-82. American Historical Association, Washington, D.C.

Harrington, Mark R.

1920 Certain Caddo Sites in Arkansas. Indian Notes and Monographs, Miscellaneous I0. Museum of the American Indian, Heye Foundation, New York.

Harris, R. King

1953 The Sam Kaufman Site, Red River County, Texas. Bulletin of the Texas Archeological Society 24:43-68.

Harisse, Henry

1892 The Discovery of North America: A Critical Documentary and Historical Investigations. London and Paris.

Hatcher, Mattie Austin

1927 Myths of the Tejas Indians. Publications of the Texas Folklore Society 6:107-118.

1932 The Expedition of Don Domingo Teran de los Rios into Texas. Preliminary Studies of the Texas Catholic Historical Society 2(1):3-67. 
Heusinger, Edward W.

1936 Early Explorations and Mission Establishments in Texas. Naylor Co., San Antonio.

Hickerson, Daniel A.

1996 Historical Processes, Epidemic Diseases, and the Formation of the Hasinai Confederacy. Ethnohistory 44(1):31-52.

Hidalgo, Fray Francisco

1927 Descriptions of the Tejas or Asinai Indians, 1691-1722. Translated from the Spanish by Mattie Austin Hatcher. Part III: Fray Francisco Hidalgo to the Viceroy and Fray Francisco Hidalgo to Fray Isidro Cassos. Southwestern Historical Quarterly31:50-62.

Hodge, Frederick W. (editor)

1907-1910 Handbook of American Indians North of Mexico. Bulletin 30, Parts 1 and 2. Bureau of American Ethnology, Smithsonian Institution, Washington, D.C.

Hodges, Dr. and Mrs. T. L.

1945 Suggestions for Identification of Certain Mid-Ouachita Pottery as Cahinnio Caddo. Bulletin of the Texas Archeological and Paleontological Society 16:98-116.

Hodges, Mrs. T. L.

1957 The Cahinnio-Caddo: A Contact Unit in the Eastern Margin of the "Caddo Area." Bulletin of the Texas Archeological Society 28:190-197.

Hooper, Alban W.

1932 Indian Affairs and Their Administration, with Special Reference to the Far West, 1849-1860. University of Pennsylvania, Philadelphia.

Hudson, Charles

1997 Knights of Spain, Warriors of the Sun. University of Georgia Press, Athens.

Hughes, Jack T.

1968 Prehistory of the Caddoan-Speaking Tribes. Ph.D. dissertation, Columbia University, New York.

Hunt, Charles B.

1967 Physiography of the United States. W. H. Freeman and Co., San Francisco.

Jackson, A. T.

1936 A "Perpetual Fire" Site. Bulletin of the Texas Archeological and Paleontological Society 8:134-173.

Jackson, Jack (editor)

2000 Texas by Teran: The Diary Kept by General Manuel de Mier y Teran on his 1828 Inspection of Texas. University of Texas Press, Austin.

Jelks, Edward B. and Curtis D. Tunnell

1959 The Harroun Site, A Fulton Aspect Component of the Caddoan Area, Upshur County, Texas. Archaeology Series No. 2. Department of Anthropology, The University of Texas at Austin. 
Jurney, David H.

2001 Diaspora of the Alabama-Koasati Indians Across Southeastern North America. Ph.D. dissertation, Department of Anthropology, Southern Methodist University, Dallas.

Kelley, David B. (editor)

1997 Two Caddoan Farmsteads in the Red River Valley. Research Series No. 51. Arkansas Archeological Survey, Fayetteville.

Kenmotsu, Nancy A.

2001 Salt Well Slough (41RR204). Bulletin of the Texas Archeological Society 72:213222.

Kenney, M. M.

1897 Tribal Society among Texas Indians. Quarterly of the Texas State Historical Association 1:26-33.

Koch, Clara L.

1925 The Federal Indian Policy in Texas, 1845-1860. Southwestern Historical Quarterly 29(2):98-127.

Kricger, Alex D.

1946 Culture Complexes and Chronology in Northern Texas. University of Texas Publications No. 4640. Austin.

LaVere, David L.

1998 The Caddo Chiefdoms: Caddo Economics and Politics, 700-1835. University of Nebraska Press, Lincoln.

Lee, Dayna B. (editor)

2001 Regional Variation and Protohistoric Identity: A Round Table Discussion from the $43^{\text {rd }}$ Caddo Conference. Caddoan Archeology 12(2/3):10-35.

Lesser, Alexander

1979 Caddoan Kinship Systems. Nebraska History 60(2):260-271.

Lesser, Alexander and Gene Weltfish

1932 Composition of the Caddoan Linguistic Stock. Miscellaneous Collections 87(6). Smithsonian Institution, Washington, D.C.

Marcy, R. B.

1855 Report of an Expedition to the Sources of the Brazos and Big Wichita Rivers, During the Summer of 1854. Senate Executive Document No. 60, $34^{\text {th }}$ Congress, $1^{\text {st }}$ Session, Vol. 12. Washington, D.C.

Margry, Pierre

1875-1886 Decouvertes et Etablissments des Francais dans l'Ouest et dans le Sud de l'Amerique Septentrionale (1614-1754). Memoires et Documents Inedits. 6 Vols. Paris.

Meredith, Howard

2001 Cultural Conservation and Revival: The Caddo and Hasinai Post Removal Era, 1860-1902. The Chronicles of Oklahoma LXXII(3):278-287. 
Mooney, James

1896 Ghost Dance Religion and Songs of the Caddo. Bulletin 14(2):1092-1102. Bureau of American Ethnology, Smithsonian Institution, Washington, D.C.

Moore, Clarence B.

1908 Certain Mounds of Arkansas and Mississippi. Journal of the Academy of Natural Sciences of Philadelphia 13(4):481-557.

1912 Some Aboriginal Sites on Red River. Journal of the Academy of Natural Sciences of Philadelphia, Second Series 14(4).

1913 Some Aboriginal Sites in Louisiana and Arkansas. Journal of the Academy of Natural Sciences of Philadelphia, Second Series 16(1).

Morfi, Fray Juan Agustin de

1932 Excerpts from the Memorias for the History of the Province of Texas. Appendix, prolog, and notes by Frederick M. Chabot.

1935 History of Texas, 1673-1779. Translated, with biographical introduction and annotations by C. E. Castaneda. 2 Parts. Quivira Society, Albuquerque.

Muckleroy, Anna

1923 The Indian Policy of the Republic of Texas. Southwestern Historical Quarterly 26(1).

Neighbors, Robert S.

1847 Report to Commissioner of Indian Affairs, October 12, 1847. Senate Executive Document NO. 1, $30^{\text {th }}$ Congress, $1^{\text {st }}$ Session, pp. 903-906. Washington, D.C.

Newcomb, William W., Jr.

2001 Wichita. In Handbook of North American Indians, Plains, Volume 13, edited by Raymond J. DeMallie, pp. 548-566. Smithsonian Institution, Washington, D.C.

Newell, H. Perry and Alex D. Krieger

1949 The George C. Davis Site, Cherokee County, Texas. Memoirs No. 5. Society for American Archaeology.

Newkumet, Vynola B. and Howard L. Meredith

1988 Hasinai:A Traditional History of the Caddo Confederacy. 'Texas A\&M University Press, College Station.

Nye, Capt. W. S.

1937 Carbine and Lance: The Story of Old Fort Sill. University of Oklahoma Press, Norman.

Orr, Kenneth G.

1952 Survey of Caddoan Area Archeology. In Archeology of Eastern United States, edited by James B. Griffin. University of Chicago Press, Chicago.

Padilla, Juan Antonio

1919 Texas in 1820. Translated by Mattie Austin Hatcher. I: Report on the Barbarous Indians of the Province of Texas. Southwestern Historical Quarterly23(1):47-68. 
Parks, Douglas R.

2001 Kitsai. In Handbook of North American Indians, Plains, Volume 13, edited by Raymond J. DeMallie, pp. 567-571. Smithsonian Institution, Washington, D.C.

Parsons, Elsie C.

1941 Notes on the Caddo. Memoirs No. 57. American Anthropological Association, Washington, D.C.

Pena, Don Juan Antonio de la

1935 Pena's Diary of the Aguayo Expedition. Translated by Rev. Peter P. Forrestal. Preliminary Studies of the Texas Catholic Historical Society 2.

Perttula, Timothy K.

1992 "The Caddo Nation": Archaeological and Ethnohistoric Perspectives. University of Texas Press, Austin.

1993 Kee-Oh-Na-Wah'-Wah: The Effects of European Contact on the Caddoan Indians of Texas, Louisiana, Arkansas and Oklahoma. In Ethnohistory and Archaeology: Approaches to Postcontact Change in the Americas, edited by J. Daniel Rogers and Samuel M. Wilson, pp. 89-109. Plenum Press, New York.

1996 Caddoan Area Archaeology since 1990. Journal of Archaeological Research 4(4):295-348.

2001 "The Great Kingdom of the Tejas": The Life and Times of Caddo Peoples in Texas between ca. 1530-1859. Bulletin of the Texas Archeological Society 72:73-89.

Perttula, Timothy K. and James E. Bruseth (editors)

1998 The Native History of the Caddo: Their Place in Southeastern Archeology and Ethnohistory. Studies in Archeology 30. Texas Archeological Research Laboratory, The University of Texas at Austin.

Pertula, Timothy K., Ann M. Early, Lois E. Albert, and Jeffrey Girard (compilers and editors)

1999 Caddoan Bibliography: Archaeology and Bioarchaeology, Ethnohistory and Ethnography, and History. Technical Paper 10. Arkansas Archeological Survey, Fayctteville.

Perttula, Timothy K., Myles R. Miller, Robert A. Ricklis, Daniel J. Prikryl, and Christopher Lintz

1995 Prehistoric and Historic Aboriginal Ceramics in Texas. Bulletin of the Texas Archeological Society 66:175-235.

Powell, J. W.

1891 Indian Linguistic Familics of America North of Mexico. $7^{\text {th }}$ Annual Report of the Bureau of American Ethnology 1885-1886, pp. 1-142. Bureau of American Ethnology, Smithsonian Institution, Washington, D.C.

Robertson, James (editor and translator)

1933 True Relation of the Hardships Suffered by Governor Fernando de Soto and Certain Portuguese Gentlemen During the Discovery of the Province of Florida, Now Newly Set Forth by a Gentleman of Elvas. Publications of the Florida State Historical Society No. 11, Vol. 2. 
Roemer, Ferdinand

1935 Texas, with Particular Reference to German Immigration and the Physical Appearance of the Country. Translated from the German by Oswald Mueller. Naylor Co., San Antonio.

Royce, Charles C.

1899 Indian Land Cessions in the United States. 18 th Annual Report of the Bureau of American Ethnology, 1896-1897, Part 2. Bureau of American Ethnology, Smithsonian Institution, Washington, D.C.

Sabo, George III

1987 Reordering their World: A Caddoan Ethnohistory. In Visions and Revisions: Ethnohistoric Perspectives on Southern Cultures, edited by George Sabo III and William M. Schncider, pp. 7-27. University of Georgia Press, Athens.

1998 The Structure of Caddo Leadership in the Colonial Era. In The Native History of the Caddo: Their Place in Southeastern Archeology and Ethnohistory, edited by Timothy K. Perttula and James E. Bruseth, pp. 159-174. Studies in Archeology 30. Texas Archeological Research Laboratory, The University of Texas at Austin.

Sanchez, Jose Maria

1926 A Trip to Texas in 1828. Translated by Carlos E. Castancda. Southwestern Historical Quarterly29:249-288.

Schambach, Frank F.

2000 Spiro and the Tunica: A New Interpretation of the Role of the Tunica in the Culturc History of the Southeast and the Southern Plains, A.D. 1100-1750. In Arkansas Archaeology: Essays in Honor of Dan and Phyllis Morse, edited by Robert C. Mainfort, Jr. and Marvin D. Jeter, pp. 169-224. University of Arkansas Press, Fayetteville.

Schambach, Frank F. and John E. Miller

1984 A Description and Analysis of the Ccramics. In Cedar Grove: An Interdisciplinary Investigation of a Late Caddo Farmstead in the Red River Valley, edited by Neal L. Trubowitz, pp. 109-170. Rescarch Series No. 23. Arkansas Archeological Survey, Fayetteville.

Schoolcraft, Henry R.

1851-1857 Historical and Statistical Information Respecting the History, Condition and Prospects of the Indian Tribes of the United States. 6 Vols. Philadelphia.

Scurlock, J. Dan

1965 The Kadohadacho Indians: A Correlation of Archeological and Documentary Data. Master's thesis, The University of 'Texas at Austin.

Shelby, Charmion C.

1923 St. Denis's Declaration Concerning Texas in 1717. Southwestern Historical Quarterly26(3): I65-183.

1924 St. Denis's Second Expedition to the Rio Grande, 1716-1719. Southwestern Historical Quarterly27(3):190-216. 
Sibley, John

1832 Historical Sketches of the Several Indian Tribes in Louisiana, South of the Arkansas River, and Between the Mississippi and River Grande. American State Papers, Class II, Indian Affairs 1, pp. 721-731.

1922 A Report from Natchitoches in 1807. Edited, with an introduction by Annie Heloise Abel. Indian Notes and Monographs, Muscum of the American Indian, Heye Foundation, New York.

Smith, F. Todd

1995 The Caddo Indians: Tribes at the Convergence of Empires, 1542-1854. Texas A\&M University Press, College Station.

1996 The Wichita and Caddo Indians-Relations with the U.S., 1846-1901. Texas A\&M University Press, College Station.

Smith, Ralph A. (translator and annotator)

1958-1959 Account of the Journey of Bernard la Harpe: Discovery Made by Him of Several Nations Situated in the West. Southwestern Historical Quarterly 62:246259, 371-385.

Solis, Fray Gaspar Jose de

1931 Diary of a Visit of Inspection of the Texas Missions Made by Fray Gaspar Jose de Solis in the Year 1767-1768. Translated by Margaret Kenney Kress. Southwestern Historical Quarterly 35:28-76.

Spier, I eslie

1924 Wichita and Caddo Relationship Terms. American Anthropologist 26(2):258-263.

Story, D. A.

1990 Cultural History of the Native Americans. In The Archeology and Bioarcheology of the Gulf Coastal Plain, by D. A. Story, J. A. Guy, B. A. Burnett, M. D. Freeman, J. C. Rose, D. G. Steele, B. W. Olive, and K. J. Reinhard, pp. 163-366. 2 Vols. Research Scries No. 38. Arkansas Archeological Survey, Fayetteville.

1997 1968-1970 Archeological Investigations at the George C. Davis Site, Cherokee County, Texas. Bulletin of the Texas Archeological Society 68:1-113.

1998 The George C. Davis Site: Glimpses into Early Caddoan Symbolism and Ideology. In The Native History of the Caddo: Their Place in Southeastern Archeology and Bioarcheology, edited by T. K. Pertula and J. E. Bruseth, pp. 9-43. Studies in Archeology 30. Texas Archeological Research Laboratory, The University of Texas at Austin.

Strickland, Rex W.

1937 Anglo-American Activities in Northeastern Texas, 1803-1845. Ph.D. dissertation, Department of History, The University of Texas at Austin.

Suhm, Dee Ann, Alex D. Krieger, and Edward B. Jelks

1954 An Introductory Handbook of Texas Archeology. Bulletin of the Texas Archeological Society 25 (whole volume). 
Swanton, John R.

1931 The Caddo Social Organization and Its Possible Historical Significance. Journal of the Washington Academy of Science 2I(9):203-206.

1942 Source Materialon the History and Ethnology of the Caddo Indians. Bulletin 132. Bureau of Amcrican Ethnology, Smithsonian Institution, Washington, D.C.

1952 The Indian Tribes of North America. Bulletin 145. Bureau of American Ethnology, Smithsonian Institution, Washington, D.C.

Thurmond, J. P.

1990 Archeology of the Cypress Creek Drainage Basin, Northeastern Texas and Northwestern Louisiana. Studies in Archeology 5. Texas Archeological Research Laboratory, The University of Texas at Austin.

Tunnell, C. D.

2000 A Landmark Court Decision in Southern Texas on Peyote and the Native American Church. Special Publication No. 8. The Southern Tcxas Archaeological Association, San Antonio.

U. S. Bureau of Indian Affairs

1963 U.S. Indian Population (1962) and Land (1963). Bureau of Indian Affairs, Washington, D.C.

1971 Estimates of the Indian Population Served by the Bureau of Indian Affairs: March 1971. U.S. Department of the Interior, Bureau of Indian Affairs, Statistical Division.

U.S. Dc Soto Commission

1939 Final Report of the U.S. De Soto Expedition Commission. House Document 71, $76^{\text {th }}$ Congress, $1^{\text {st }}$ Session. Washington, D.C.

Varner, John G. and Jeanettc J. Varner (translators and editors)

1951 The Florida of the Inca. University of Texas Press, Austin.

Voegelin, C. F.

1941 North American Indian Languages Still Spoken and Their Genetic Relationships. In Language, Culture, and Personality, edited by Leslie Spier, A. Irving Hallowcll, and Stanley S. Newman, pp. 15-40. Sapir Memorial Publication Fund, Menasha, Wisconsin.

Walker, Winslow $\mathrm{M}$.

1931 A Caddo Burial Site at Natchitoches, Louisiana. Miscellaneous Colloctions 94(14). Smithsonian Institution, Washington, D.C.

Webb, Clarence $\mathrm{H}$.

1940 House Types among the Caddo Indians. Bulletin of the Texas Archeological and Paleontological Society 12:49-75.

1945 A Second Historic Caddo Site at Natchitoches, Louisiana. Bulletin of the Texas Archeological and Paleontological Society 16:52-83.

1959 The Belcher Mound: A Stratified Caddoan Site in Caddo Parish, Louisiana. Memoirs No. 16. Society for American Archaeology, Salt Lake City. 
1960 A Review of Northeast Texas Archeology. Bulletin of the Texas Archeological Society 29:35-62.

Webb, Walter P. (cditor)

I952 The Handbook of Texas. 2 Vols. Texas State Historical Association, Austin.

Wedel, Mildred Mott

1978 La Harpe's 1719 Post on the Red River and Nearby Caddo Settlements. Bulletin No. 30. Texas Memorial Museum, Austin.

Weer, Paul

1938 Preliminary Notes on the Caddoan Family. Prehistory Research Series, Indiana Historical Society, Indianapolis.

Williams, Stephen

1964 The Aboriginal Location of the Kadohadacho and Related Tribes. In Explorations in Cultural Anthropology, edited by Ward H. Goodenough, pp. 545-570. McGrawHill Book Co., New York.

Wilmsen, Edwin N.

1961 A Suggested Developmental Sequence for House Forms in the Caddoan Area. Bulletin of the Texas Archeological Society 30:35-49.

Winfrey, Dorman H. (editor)

1959-1960 Texas Indian Papers. 3 Vols. Texas State Library, Austin.

Woodall, J. Ned

1969 Cultural Ecology of the Caddo. Ph.D. dissertation, Southern Methodist University, Dallas.

Wright, Muriel $\mathrm{H}$.

1951 A Guide to the Indian Tribes of Oklahoma. University of Oklahoma Press, Norman.

Wyckoff, D. G.

1980 Caddoan Adaptive Strategies in the Arkansas Basin, Eastern Oklahoma. Ph.D. dissertation, Department of Anthropology, Washington State University, Pullman.

Wyckoff, Don G. and Timothy G. Baugh

1980 Early Historic Hasinai Elites: A Model for the Material Culture of Governing Elites. Midcontinental Journal of Archaeology 5:225-283.

Young, Gloria A. and Michael P. Hoffman (editors)

1993 The Expedition of Hernando de Soto West of the Mississippi, 1541-1543: Proceedings of the De Soto Symposia, 1988 and 1990. University of Arkansas Press, Fayetteville.

Zavala, A. de

1915 Religious Beliefs of the Tejas or Hasinai Indians. Publications of the Texas Folklore Society 1:39-43. 